\title{
The Doctrinal Method: Incorporating Interdisciplinary Methods in Reforming the
} Law

\author{
Terry Hutchinson*
}

\begin{abstract}
The doctrinal methodology is in a period of change and transition. Realising that the scope of the doctrinal method is too constricting, academic lawyers are becoming eclectic in their use of research method. In this transitional time, legal scholars are increasingly infusing evidence (and methods) from other disciplines into their reasoning to bolster their reform recommendations.

This article considers three examples of the interplay of the discipline of law with other disciplines in the pursuit of law reform. Firstly the article reviews studies on the extent of methodologies and reformist frameworks in PhD research in Australia. Secondly it analyses a 'snapshot' of recently published Australian journal articles on criminal law reform. Thirdly, it focuses on the law reform commissions, those independent government committees that play such an important role in law reform in common law jurisdictions.

This examination demonstrates that while the doctrinal core of legal scholarship remains intact, legal scholars are endeavouring to accommodate statistics, comparative perspectives, social science evidence and methods, and theoretical analysis, within the legal research framework, in order to provide additional ballast to the recommendations for reform.
\end{abstract}

Keywords: doctrinal research, interdisciplinary methods, law reform

\section{The Context}

Like the Roman god Janus who is portrayed with two faces one looking to the past and the other to the future, the doctrinal methodology has strong roots in the past, but it is now transitioning towards an electronic globalised future. This discussion concentrates on the future of legal scholarship and the evolving taxonomy for incorporation of insights from other disciplines, particularly the social sciences, into reform-oriented legal research.
Even when a non-legal response might be just as appropriate to resolve a broader social problem, doctrinal researchers have tended to continue to work within the parameters of the discipline in order to make recommendations for reform. They have confined their research to a critical analysis and synthesis of the law. However, realising that the scope of the doctrinal method is too constricting, academic lawyers are becoming eclectic in their use of research method. Legal scholars may not often utilise non-doctrinal methods themselves, but they do include the results of the use of these methods in their research. In this transitional time, legal academics are increasingly infusing evidence (and methods) from other disciplines into their reasoning to bolster their reform recommendations. Current studies suggest that this is not occurring to the same extent within the law reform commissions. ${ }^{1}$

This article considers three examples of research and writings by lawyers which are directed to law reform. This analysis examines the extent of the interplay between doctrinal analysis and research from non-doctrinal research methodologies within these sets of materials. Firstly the article reviews studies on the extent of methodologies and reformist frameworks in $\mathrm{PhD}$ research in Australia. Secondly it analyses a 'snapshot' of recently published Australian journal articles on criminal law reform. Thirdly it focuses on the law reform commissions, those independent government committees that play such an important role in law reform in common law jurisdictions.

This examination demonstrates that while the doctrinal core of legal scholarship survives intact, legal scholars are, to some extent, endeavouring to accommodate statistics, comparative perspectives, social science evidence and methods, and theoretical analysis, within the legal research framework, in order to provide additional ballast to the recommendations for reform. 


\section{Clarifying the Basics: What Is Doctrinal Research?}

Historically, doctrinal analysis has been the dominant legal method in the common law world, although other categories of research such as reform oriented, theoretical, and fundamental have been acknowledged as important and to this extent doctrinal research has always included an interdisciplinary aspect. Nevertheless, legal academic success has been measured within a doctrinal methodology framework, which includes the tracing of legal precedent and legislative interpretation. The essential features of doctrinal scholarship involve 'a critical conceptual analysis of all relevant legislation and case law to reveal a statement of the law relevant to the matter under investigation'. ${ }^{2}$ There is general consensus on this type of broad description. This 'conceptual analysis critique' is based on an understanding of the rules of precedent between the court jurisdictions, the rules of statutory interpretation, the tacit discipline knowledge such as the difference between civil and criminal jurisdictions, and various tests of liability, along with the acknowledged reasoning methods, borrowed from philosophy and logic, such as induction and deduction.

How does the doctrinal method relate to law's discipline paradigm? Thomas Kuhn viewed paradigms as a shared frame of reference among researchers, which could be upset by new revelations leading to generational struggles between newer and more established researchers. ${ }^{3}$ Thus, paradigms are shared worldviews within a discipline, which determine what topics are 'suitable' to study, what methodologies are acceptable, and what criteria may be used to judge success. Other descriptions of paradigms include 'taken-for-granted mind sets', and according to this view, socialisation into the discipline is instrumental in ensuring that newcomers take on these 'ways of knowing'. ${ }^{4}$ A discipline paradigm encompasses any underlying philosophies, which again, in the common law world, has been predominantly liberalism, with its ideas of rationalism, the importance of personal property and individual self-determination. There are other aspects to the paradigm - the once-prevalent view of law as being objective and neutral, and positivism, with its view of law as being 'what is' rather than what 'could be' or 'should be' also form part of the paradigm. These characteristics are particularly ubiquitous in the British common law legal tradition. The established paradigm within research in the discipline of law has involved the individual scholar's legal voice.

So doctrinal research was the predominant category identified in all the discipline assessments for law that

2. T. Hutchinson, 'Valé Bunny Watson? Law Librarians, Law Libraries and Legal Research in the Post-Internet Era', 106(4) Law Library Journal 579, at 584 (2014).

3. T. Kuhn, The Structure of Scientific Revolutions (1996).

4. J. Jones, 'Undergraduate Students and Research', in O. Zuber-Skerritt (ed.), Starting Research - Supervision and Training (1992), at 54 took place in the 1980s. ${ }^{5}$ In 1987, the Australian Pearce Committee highlighted doctrinal as the main category in its research taxonomy, describing it as research which 'provides a systematic exposition of the rules governing a particular legal category, analyses the relationship between rules, explains areas of difficulty and, perhaps, predicts future developments'. ${ }^{6}$ The Council of Australian Law Deans subsequently expanded on this earlier definition - 'Doctrinal research, at its best, involves rigorous analysis and creative synthesis, the making of connections between seemingly disparate doctrinal strands, and the challenge of extracting general principles from an inchoate mass of primary materials'. ${ }^{7}$ In 2006, Martha Minow, Dean of Harvard Law School, identifies 'doctrinal restatement' as one of the main contributions legal scholars make within their research. ${ }^{8}$ Susan Bartie identifies 'doctrinalism' as a 'unifying element in legal scholarship in England and Australia'. ${ }^{9}$ Writing from a European perspective in 2011, Rob van Gestel and H.-W. Micklitz, describe the process in similar terms stating that in doctrinal work, 'arguments are derived from authoritative sources, such as existing rules, principles, precedents, and scholarly publications.' ${ }^{10}$ Accordingly, they continue, the law 'somehow represents a system' so that 'through the production of general and defeasible theories, legal doctrine aims to present the law as a coherent net of principles, rules, meta-rules and exceptions, at different levels of abstraction', and 'decisions in individual cases are supposed to exceed arbitrariness because they have to fit into the system' so that the system remains coherent. ${ }^{11}$ Therefore, there is widespread agreement on the basic tenets of doctrinal research.

The doctrinal method has been widely criticised, largely because it has never been explicated sufficiently for non-lawyers - or for lawyers themselves! ${ }^{12}$ Legal researchers have not been in the practice of describing their methodologies even within their academic work. In the past, few $\mathrm{PhD}$ theses have provided a separate description detailing the extent of the method. The method is assumed knowledge within the discipline part of the grab-bag of skills associated with 'thinking like a lawyer'. The doctrinal method is qualitative and idiosyncratic and, especially in the courts and in prac-

5. H. Arthurs, Law and Learning: Report to the Social Sciences and the Humanities Research Council of Canada by the Consultative Group on Research and Education in Law (1983), at 66; D. Pearce, E. Campbell \& D. Harding, Australian Law Schools: A Discipline Assessment for the Commonwealth Tertiary Education Commission (1987).

6. Pearce, Campbell \& Harding, above n. 5, 2, 312 [9.17]

7. Council of Australian Law Deans, Statement on the Nature of Legal Research (2005), at 3.

8. M. Minow, 'Archetypal Legal Scholarship - A Field Guide', 63(1) Journal of Legal Education 65-69, at 65 (2013).

9. S. Bartie, 'The Lingering Core of Legal Scholarship', 30(3) Legal Studies 345 , at 350 (2010).

10. R. Van Gestel and H-.W. Micklitz, ‘Revitalizing Doctrinal Legal Research in Europe: What About Methodology?', European University Institute Working Papers Law (2011)/05, at 26.

11. Ibid.

12. W. Twining, Taylor Lectures 1975 Academic Law and Legal Development (1976) (Lagos: University of Lagos Faculty of Law). 
tice, the outcomes are often limited to the specific facts of the case. As a way of combating criticism from the physical sciences, Christopher Langdell, in the early part of the nineteenth century, had tried to promote law as a 'legal science', and the law library as a 'lawyer's laboratory'. In the Preface to Contracts, he commented: ${ }^{13}$

Law, considered as a science, consists of certain principles or doctrines. ... Each of these doctrines has arrived at its present state by slow degrees; in other words, it is a growth, extending in many cases through centuries. This growth is to be traced in the main through a series of cases. ... Moreover, the number of fundamental legal doctrines is much less than is commonly supposed. ... If these doctrines could be so classified and arranged that each should be found in its proper place, and nowhere else, they would cease to be formidable from their number. ... It seemed to me, therefore, to be possible ... to select, classify, and arrange all the cases which had contributed in any important degree to the growth, development, or establishment of any of its essential doctrines. ${ }^{14}$

A few years later, in the Harvard Law School Annual Report, Langdell again noted:

'The work done in the Library is what the scientific men call original investigation. The Library is to us what a laboratory is to the chemist or the physicist, and what a museum is to the naturalist'. ${ }^{15}$ In this respect Langdell was suggesting that the law 'ought to be studied from its own concrete phenomena, from law cases, in the same way that the laws of the physical sciences are derived from physical phenomena and experiments' ${ }^{16}$ Historically, the doctrinal process has been described within a problem framework with a number of linear steps including assembling the facts, identifying the legal issues, analysing the issues with a view to searching for the law, undertaking background reading and then locating primary material, synthesising all the issues in context, and coming to a tentative conclusion. ${ }^{17}$ There is certainly a need for a more sophisticated approach to tease out the doctrinal method. Whether the doctrinal method can ever be stated in a formulaic way is problematic. At its heart it is fluid. It is difficult to reduce to an algorithm.

\subsection{Additional Categories of Legal Research}

Doctrinal research was not the only type of research categorised within the early discipline reviews. The reports categorised other methodologies such as law reform research, legal theory research, and fundamental re-

13. B. Kimball, The Inception of Modern Professional Education: C.C. Langdell, 1826-1906 (2009), at 349, app., 2.

14. C.C. Langdell, A Selection of Cases on the Law of Contracts (1871) from Kimball, above n. 13 (emphasis added).

15. C.C. Langdell, Annual Report 1873-74 from Kimball, above n. 13, at 67, 349, app., 2.

16. Kimball, above n. 13, at 351, app., 2, n. 10; J. Redlich, The Common Law and the Case Method in American University Law Schools (1914), at 15 .

17. T. Hutchinson, Researching and Writing in Law (2010) 41, at 42. search separately. ${ }^{18}$ The Pearce Committee acknowledged 'reform-oriented' research, research which 'intensively evaluates the adequacy of existing rules and which recommends changes to any rules found wanting', as a separate category. ${ }^{19}$ Arguably what was being delineated here was also a form of doctrinal research. Pure doctrinal research identifies and analyses the current law. Reform-oriented research recommends change. Most 'good' quality doctrinal research goes well beyond description, analysis, and critique, and invariably suggests ways the law could be amended or the philosophy, processes or administration of the law could be improved. In many common law jurisdictions, there are separate organisations working to develop a reform agenda, these being the law reform commissions. These are discussed at more length later in this article. The reform-oriented research taking place in the commissions was primarily doctrinal, but depending on resources, had a consultative aspect and the potential to be 'interdisciplinary' in its methods. ${ }^{20}$

The third type of research identified in the Pearce Committee Report was theoretical research - 'research which fosters a more complete understanding of the conceptual bases of legal principles and of the combined effects of a range of rules and procedures that touch on a particular area of activity'. ${ }^{21}$ Legal theory is a crucial tool to provide a critical perspective on the law. However, in the past, the utility of theoretical research may have been diminished because of the limited exposure of the profession to theory (and the language of theory) and also because of the seeming gap between legal theory and practice. ${ }^{22}$ Lawyers, even academic lawyers, have been so steeped in positivism that they have not sufficiently fostered knowledge of legal theory and the skills of critique and applied this to the law.

Certainly this is not the case currently. Research activity at postgraduate level always includes a conceptual framework, a component of which is the theory underlying the law itself, and the philosophy that best encapsulates the researcher's view of the law. In the postmodern world, legal researchers understand that nothing is objective. Even the choice of topic for examination depends on the researcher's world view. Very few doctrinal researchers would not acknowledge that fact in the twenty-first century.

The Canadian Arthurs Report identified a further category - 'Research designed to secure a deeper understanding of law as a social phenomenon, including research on the historical, philosophical, linguistic, economic, social or political implications of law', or fundamental research. ${ }^{23}$ This type of research treats law as a phenomenon, as a problem with cause and effect. ${ }^{24}$ Fun-

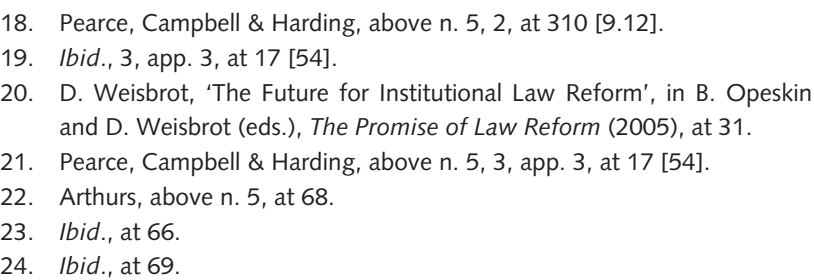


damental research uses social science methodologies to examine the law through the prism of another discipline's. view - the economist or linguist or criminologist. Can fundamental research include a doctrinal component? On the basis that all research on law necessarily acknowledges the law as its basis then the answer to that must be a resounding 'yes'. Interdisciplinary legal articles, even those being written by non-lawyers from an 'outsider' view, frequently acknowledge the 'black letter' or 'doctrinal core' of law as the starting point, whatever methodology is being used to pursue the author's agenda. $^{25}$ Once again there must be an acknowledgement that the boundaries between the various categories are not closed in the present century. The methodology denotes the difference.

There are at least two other important categories of legal research which were not categorised separately in the reports in the 1980s. These are policy research and comparative research. Public policy research normally takes place within government departments rather than in academia but it too has a doctrinal component. There is certainly a cross-over with the methods used by the institutional law reform commissions because the process includes public consultation, discussion papers, public submissions, surveys, public meetings, and written reports. The difference lies in the degree of political interference in public policy outcomes. The policy inquiries are funded and driven by politicians, whereas law reform terms of reference emanate from government, and the research is conducted independently of departmental interference.

Martha Minow identifies 'Comparative and Historical Inquiries' as another typology or 'intellectual contribution' of legal scholarship which 'Describe an earlier era or contrasting legal regime; Contextualize the selected era or regime utilizing social sciences such as anthropology or history; and Illuminate differences, choices, or continuities when compared with contemporary domestic practice'. ${ }^{26}$ Despite not being placed in a separate category, comparative research was acknowledged in the earlier taxonomies which included statements about the need for lawyers to 'keep up' with the 'legal and other relevant literature of all common law jurisdictions including England, New Zealand, Canada and the United States'. ${ }^{27}$

From this discussion it is evident that there is a need for a new interdisciplinary taxonomy that recognises the interplay of the changing methods and purposes within the legal discipline paradigm. Kuhn suggests that paradigms can and do change and there is no doubt that this is occurring within the discipline of law. The examples examined in Section 3 of this article demonstrate that the paradigm of the sole researchers working at their computer and involved in qualitative doctrinal scholarship remains. Even so, although the scholars do not always apply the non-doctrinal methods themselves,

25. Bartie, above n. 9.

26. Minow, above n. 8, at 68 .

27. Pearce, Campbell \& Harding, above n. 5, 3, app. 3 at 17 [53] there is an increasing application of the research results from the use of such methods by legal scholars. The door is definitely ajar to further change though the link between doctrinal and non-doctrinal needs to be better articulated and explored.

\section{Examining Methodologies Informing Recommendations}

If we accept the methodological ground rules for doctrinal work, with the simplistic problem based structure as a naive framework, and also recognise that theory, fundamental research, comparative research, and law reform have always played a role within the discipline's research landscape but often as separate genres, the next issue is to examine how non-doctrinal methodologies are being infused into legal research in the twenty-first century. Is this fundamentally changing the doctrinal method? Are lawyers using non-doctrinal methodologies and data as a matter of course? At what point in the analysis is this data being infused into the discussion and how is this evidence being synthesised with the law in coming to a conclusion or recommendation for reform? What is current practice and how valid are the outcomes or any recommendations for change based on the studies? Is there adequate internal cohesion in the analysis reinforcing the recommendations? These are difficult questions and this article can only hope to provide basic assessments of trends using examples of previous studies on $\mathrm{PhD}$ theses, a snapshot of recent articles written by lawyers for Australian law journals and the studies of outputs of the law reform commissions.

\subsection{Interdisciplinarity Evidenced in PhD Theses} and Law Journal Articles

There are few empirical studies examining the methodologies employed in legal scholarship. ${ }^{28}$ Any recent studies of the use of legal research methodologies focus on the postgraduate research arena. A survey of postgraduate research in Australian law schools undertaken in 2002 demonstrated that only $20 \%$ of all doctoral research projects could be described as purely 'doctrinal'. ${ }^{29}$ A more recent examination of HDR theses submitted to the Australasian Digital Thesis Program website in the 5-year period 2004-2009 reveals that most of the legal theses include a doctrinal component, even though only a few students overtly identified the study

28. While statistical studies on methodologies being used in legal research are rare, the topic of how lawyers research is not a new area of legal academic concern. See, for example, E. Jones, 'Some Current Trends in Legal Research', 15(2) Journal of Legal Education 121 (1962-1963).

29. D. Manderson and R. Mohr, 'From Oxymoron to Intersection: An Epidemiology of Legal Research', 6 Law Text Culture 159, at 164 (2003); and see D. Manderson, 'Law: The Search for Community', in S. Marginson (ed.), Investing in Social Capital (2002), at 152 on breakdown of empirical and doctrinal PhDs in Australia. 
they were conducting as being to any extent 'doctrinal' ${ }^{30}$ According to this study, 16 of the 60 theses examined include a chapter to describe the use of non-doctrinal methodologies, 21 theses discuss methodologies as part of another chapter, and one deals with the methodology in an appendix. Any overt description of method in the thesis invariably signalled an interdisciplinary perspective, so the results demonstrate a higher proportion of doctrinal papers than occurred in the 2002 survey with $37 \%(n=22)$ in this group being purely doctrinal. This demonstrates that law is still essentially a scholarly endeavour.

There are differences between the research process and methods undertaken in a $\mathrm{PhD}$ program compared to a great deal of legal academic scholarship. PhD requirements influence the scope and the depth of analysis of any study as well as the choice of research methodology. The PhD students will usually attempt a triangulation of methods and may well base their conclusions on several different collections of research data. The categories of methods the $\mathrm{PhD}$ students choose are constrained by the supervisors' levels of expertise and the student's training. The non-doctrinal methodologies are invariably fully reported in the thesis, but the extent of doctrinal analysis is rarely acknowledged, described, or unpacked.

Following completion, the $\mathrm{PhD}$ candidates may either translate their work into a monograph or publish several separate journal articles dealing with sections of the thesis. This entails segmenting the work. Broadly speaking, different topics will be packaged for the various audiences to best disseminate the research amongst the assorted discipline audiences. The doctrinal legal analysis will be published in a university law review or topic specific law journal targeting academic and practising subject specialists. As a rule, lawyers do not 'like' detailed statistics because many have not been fully trained in statistical method, so the law journal article will not include extensive discussion of empirical work undertaken in the thesis and certainly not mathematical formulas. The theoretical framework of the project will be emphasised for a law and society or sociology journal. More practical policy and reform aspects combining the law and social science studies will be directed to subjectspecific 'current issues in the law' titles. Studies including details of the empirical analysis are diverted to the criminology and social science journals.

Undoubtedly law academics use a similar approach for publishing outputs from their larger funded and teambased projects. Different aspects of the broader studies are highlighted according to the publishing profile of the target journals. For this reason it is difficult to validly determine the total extent of methodologies being implemented by legal scholars simply by examining law journal articles.

30. T. Hutchinson and N. Duncan, 'Defining and Describing What We Do: Doctrinal Legal Research', 17(1) Deakin Law Review 83, at 99 (2012); The study of the Australasian Digital Thesis Program website was undertaken by Felicity Deane and Terry Hutchinson and completed in October 2010
Despite the existence of these limitations on assessing legal research activity, an examination was conducted of a set of journal articles on the topic of 'reform of the criminal law' which were published in 2013. This 'snapshot' of publications encompassed articles published in Australian law journals - but only those held on the AustLII database. ${ }^{31} \mathrm{~A}$ basic search string resulted in a retrieved list displaying 60 items. When book reviews, speeches, and government publications were omitted, then only thirty-two refereed journal articles remained as a relevant subset of the database. ${ }^{32}$ This subset included articles which were written by lawyers, included doctrinal analysis, and specifically dealt with 'criminal law and reform'. This entire group of articles had been published in refereed (blind peer reviewed) journals. The examination of the articles in the retrieved list focused on the author's profession (all had legal qualifications), whether the articles included a doctrinal analysis of legislation or case law, the extent of the description of additional methods, and the point at which it was introduced into the discussion. Were statistics included in the analysis and if so, where were these sourced? Where a comparison was included, the study considered whether this was contextual or a full comparison and whether there was also reference to public international law. Did the author mention law reform commission recommendations?

All the articles used a doctrinal research methodology to some extent. In two articles there was more emphasis on theory, criminology, and international law rather than an analysis of specific case law or legislation. The doctrinal methodology design was tacit; not so any non-doctrinal methods. Surveys, for example, were outlined and explained using appropriate tables. While only two of the articles were reporting that the authors had themselves undertaken surveys, interviews, or statistical projects, ${ }^{33}$ eighteen used statistics published elsewhere in discussing the basis of concerns. This provided foundation for the discussion of the prevalence of offences and involved the use of news article reports, law reform submissions, and social science studies (predominantly reports of surveys) from medical and other interdisciplinary journals. To this extent the statistics provided context for the legal discussion.

All the articles analysed pertinent secondary literature with only two including an explicit acknowledgement of the literature review. The review of the literature is an

31. Australasian Legal Information Institute $<w w w$.austlii.edu.au/ $>$.

32. These were located on the AustLII database using the search term 'crim* w/10 (reform* OR recommend*)' within the Australian journal titles published in 2013. The search was conducted on 16 February 2015. There are approximately 100 Australian journal titles on this database including most of the university law reviews.

33. M. Brown, G. Lansdell, B. Saunders \& A. Eriksson, "I'm Sorry But You're Just Not That Special ...' Reflecting on the 'Special Circumstances' Provisions of the Infringement Act 2006 (Vic)', 24(3) Current Issues in Criminal Justice 375 (2013) (semi-structured interviewing and court observations and quantitative, descriptive data extracted from CLC databases); H. Douglas and R. Fitzgerald, 'Legal Processes and Gendered Violence: Cross-Applications for Domestic Violence Protection Orders', 36(1) University of New South Wales Law Journal 56 (2013) (examination of Magistrates Court files). 
implicit quality indicator in the doctrinal methodology paradigm. The extensive footnoting used as the preferred citation style for this group of articles provides an updated record of the secondary literature on the topic. The scope and currency of these references provide a strong warrant for the author's credentials and knowledge of the subject area. Relevant texts, journal articles, and law reform publications are referenced where applicable to the discussion rather than brought together under a formal literature review heading.

Fourteen of the thirty-two articles were jointly authored, signalling a definite movement away from the lone scholar paradigm. Six of the articles disclosed their funding sources as being either from external publicly funded grants or university internal grants, and five of these were jointly authored. At least 6 of the 14 jointly authored articles emanate from subject-specific university or faculty research centres and working groups. Those articles that were jointly authored were likely to include interdisciplinary approaches, such as criminology and law, or emanate from the research centres.

The actual number of discrete comparative analyses in this retrieved group was low. Only two of the articles had as their main objective a comparison of the law between jurisdictions. However, twenty-three of the articles include a comparative review of the existing law particularly for the Australian state jurisdictions as well as pertinent examples from international jurisdictions. The Arthurs Report had recognised that comparative and historical research involving legal rules was likely to lead to 'new' solutions. ${ }^{34}$ However, their comment in 1983 was that 'experience, and our own investigation, shows that historical or comparative research is not undertaken routinely even by scholarly investigators, and rarely carried out by practitioners. Perhaps we stand on the threshold of change in this regard ...' ${ }^{35}$ The change has occurred. It is widely recognised that comparative research approaches are becoming the norm within the current doctrinal method, and this small snapshot of articles reinforces this perspective. There are discrete comparisons of legal provisions in two or three jurisdictions, comparisons of the legislation between numbers of jurisdictions in order to provide context, and at the very least the use of comparative data and information on the law in other jurisdictions using secondary literature. Law is less parochial in the twentyfirst century. Globalisation and technology mean that the wider legal sphere is more accessible and pertinent for the legal scholar. This in itself is intriguing and needs more examination to test and confirm this practice using a larger body of evidence. Certainly reports published by law reform commissions have consistently included a comparative approach. The current expectation in the literature is that there will be some statement of the legal jurisdictional status quo or an acknowledgement of obvious discrepancies in practice elsewhere.

34. Arthurs, above n. 5 , at 68

35. Ibid.
This forms part of the context of the doctrinal discussion.

Many of the articles (twenty-three) include recommendations for reforming the law informed by the evidence presented. Suggestions for reform included calls for social reform to engender change, improved data collection and review mechanisms, or specific non-legislative action. Five of the articles simply critiqued the existing laws.

Some of the limitations of this pilot study must be acknowledged openly. It might be expected that more non-doctrinal methods would be found in studies of criminal law and law reform. Studies of reform in other areas of law such as tort law or corporate law or equity might well be more legalistic in approach. There is space for more extensive studies of the published literature to gauge such differences. Overall, within this pilot study of thirty-two doctrinal articles on reform of the criminal law written by lawyers, there was evidence of an increasing reference to comparative law and to published statistics and social science evidence to contextualise the law and to reinforce the doctrinal analysis and conclusions. Studies utilising empirical methods or with a mainly theoretical focus were less common.

\subsection{Interdisciplinarity and the Work of the Law Reform Commissions}

The third study centres on the reports emanating from the law reform commissions. Before examining the research within the commissions, it is necessary to understand a little more about how the commissions function. Law reform bodies have an established role in common law history. The commissions are independent government agencies charged with the task of reforming the law. Evidence exists of law reform commissions in Scotland in 1425 and various ad hoc committees set up to reform and rationalise the law over the centuries in England, ${ }^{36}$ with law reform committees being formed in Australia from the 1870s. ${ }^{37}$ The permanent English Law Commission was established in 1965, and statutory law reform commissions on a similar model are now established in most common law jurisdictions. ${ }^{38}$ The Australian Law Reform Commission (ALRC) was established as an independent statutory body in 1975. Under s21 of the Australian Lam Reform Commission Act 1996 (Cth) the Commission's brief is to systematically develop and reform the law by:

36. W. Hurlburt, Law Reform Commissions in the United Kingdom, Australia and Canada (1986), at Chapter 2 Law Reform Commissions in the United Kingdom 15-99 generally.

37. Ibid., at 100-68: Chapter 3 Law Reform Commissions in Australia; See also Australian Law Reform Commission, Annual Report 1975 (1975), at 5-19.

38. There are Law Reform Commissions in most of the Australian jurisdictions. Canada too has multiple reform commissions or institutes, for example, The Law Reform Commission of Nova Scotia and the nonstatutory Alberta Law Reform Institute. In the United Kingdom, the Law Commission and the Scottish Law Commission are statutory commissions established by the Law Commissions Act 1965 (UK); The United States has multiple committees or commissions, for example, The California Law Revision Commission and the Michigan Law Revision Committee. 


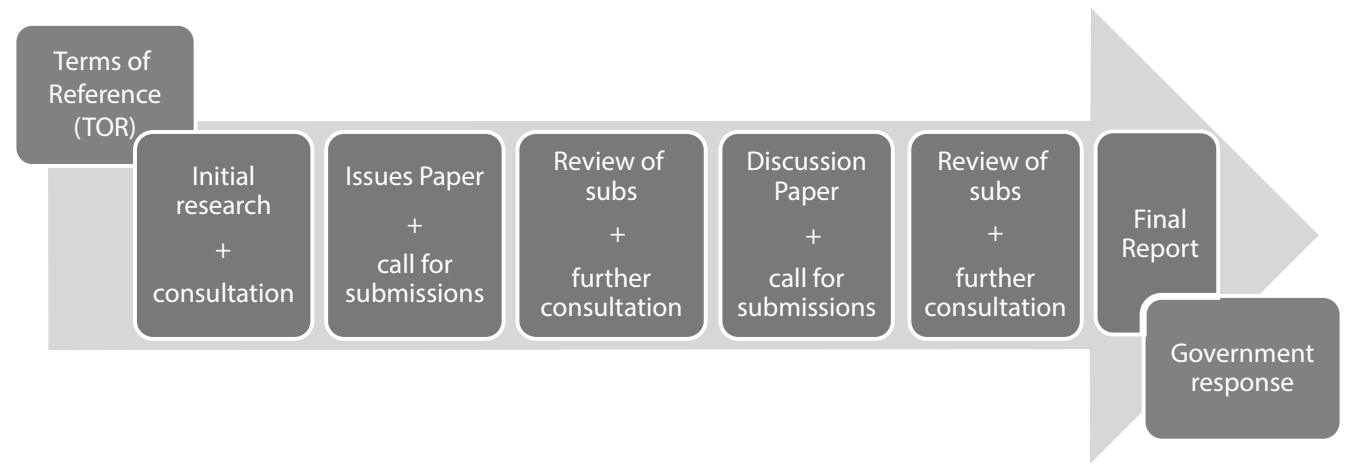

i. bringing the law into line with current conditions and ensuring that it meets current needs; and

ii. removing defects in the law; and

iii. simplifying the law; and

iv. adopting new or more effective methods for administering the law and dispensing justice; and

v. providing improved access to justice. ${ }^{39}$

The Australian state law reform commissions are, with a few exceptions, modelled on the national body, though they invariably have fewer resources. ${ }^{40}$ The terms of reference for law reform enquiries are normally set by the Attorney General in consultation with the Commission. Consultation with the general public and stakeholders is always a key element of the inquiry process. Figure 1 demonstrates the typical law reform process.

There have been trends in the popularity of law reform commissions resulting in the periodic closure and rebirth of agencies in common law jurisdictions depending on government finances and reform agendas. ${ }^{41}$ The ALRC for example has been reviewed several times since $1975 .{ }^{42}$ Possibly because of this high level of scrutiny, the Commission's Annual Reports contain very detailed information on performance and outcomes. ${ }^{43}$ The levels of implementation of all ALRC reports are reasonably high:

- $60 \%$ are substantially implemented;

- $\quad 28 \%$ are partially implemented;

- $\quad 2 \%$ are under consideration;

- $3 \%$ are awaiting response; and

- $7 \%$ have not been implemented. ${ }^{44}$

39. Australian Law Reform Commission Act 1996 (Cth), and see the Public Governance, Performance and Accountability Act 2013 (Cth).

40. Commonwealth of Australia, The Senate, Legal and Constitutional Affairs References Committee: Inquiry into the Australian Law Reform Commission (2011), at 9.

41. N. Rees, 'The Birth and Rebirth of Law Reform Agencies', Australasian Law Reform Agencies Conference 2008 Vanuatu 10-12 September (2008).

42. 1977-1979 Senate Standing Committee on Legal and Constitutional Affairs inquiry; 1993-1994 House of Representatives Standing Committee on Legal and Constitutional Affairs; 1997-1998 Possible Improper Interference with a Potential Witness before the Parliamentary Joint Committee on Native Title and the Aboriginal and Torres Strait Islander Land Fund (73rd Report); 2010-2011 Senate Legal and Constitutional Affairs Committee Inquiry into the Australian Law Reform Commission.

43. Australian Law Reform Commission, Report 125: Annual Report 2013-13 (2014), at 26.

44. Ibid., at 27 .
The law reform commissions are touted as one of the main conduits for law reform. ${ }^{45}$ However, there are many other channels available for advocating legal and regulatory change. These include 'parliamentary committees and ad hoc commissions of inquiry', ${ }^{46}$ as well as periodic reports from internal government policy units, reports from government instrumentalities such as the sentencing councils, the children's commissions, the human rights commissions, and even the courts' annual reports. Tranter has identified two possible approaches to law reform - one being the 'research institute' approach where 'recommendations are generated by experts analysing relevant data and academic literature' and the other evidencing a 'community engagement' approach where 'recommendations are located as having emerged from a process of community consultation'. ${ }^{47}$ By and large the law reform commissions fall within the latter 'community engagement' category. Many of these other bodies would be categorised as 'research institutes'.

Although comparative legal perspectives and references to published statistics feature in the reports and publications of the formally constituted law reform commissions, the principal method employed by the commissions is public consultation. Justice Kirby, the founding chair, commented that the ALRC ushered in a new era for law reform in Australia with the 'value adding' involved in public consultation. ${ }^{48}$ The current ALRC Chair, Rosalind Croucher, also champions the consultation process:

Through its widespread and thorough consultation strategies, the ALRC is able to build consensus and understanding of its proposals within the community and this assists the government in turn to implement various recommendations, even in a context where change may be challenging. ${ }^{49}$

45. Commonwealth of Australia, above n. 40, at 9 [2.18].

46. L. Barnett, 'The Process of Law Reform: Conditions for Success', 39 Federal Law Review 161 (2011).

47. Tranter, above n. 1; Barnett, above n. 46.

48. Justice Kirby has concluded that "the most original "value added" of the ALRC - and its chief contribution to the law reform technique in the years after its establishment - was its emphasis on public consultation'. M. Kirby, 'Are We There Yet?', in B. Opeskin and D. Weisbrot (eds.), The Promise of Law Reform (2005), at 435.

49. Australian Law Reform Commission, above n. 43, at 5 . 
Public consultation constitutes a non-doctrinal method and as such is interdisciplinary in its approach. However, consultation was probably not what the former Commissioner of the Law Commission of Canada, Roderick Macdonald, had in mind when in the mid-90s he was arguing for a 'reimagining' of law reform processes, including 'co-opting non-academic and academic', 'nonlegal and legal', with the notion of reform being to 'transcend doctrine' ${ }^{50}$ Macdonald advocated that law reform should be focusing on alternative reform processes (and outcomes) rather than simply presenting a report together with redrafted legislation as a standard response, and that there should be a different choice of projects moving away from substantive law topics to broader areas of social justice and the relation of law and society'. ${ }^{51}$ W.H. Hurlburt challenged all of these ideas in a spirited reply in the same issue of the journal. ${ }^{52}$ However, these methodological constraints were perceived as a failing in the Canadian Arthurs Report which held that 'the basic problem with much law reform research is rather that it is located toward the doctrinal end of the methodological spectrum, and consequently fails to confront most problematic issues' ${ }^{53}$ Greycar and Morgan perceived that the law reform bodies were using 'limited consultation processes that often leave out of account the concerns of those most affected' and disadvantaged groups. ${ }^{54}$ Greycar and Morgan provide examples of the lack of empirical methods and data in the formation of law reform recommendations in favour of so-called "common sense" anecdotal information'. 55 More recently Angela Melville's comparison between New Zealand and Canadian law reform commissions pointed out the difference in approaches. ${ }^{56}$ Melville noted the methodological insularity, 'top down' approach and even paternalistic attitude exhibited by some commissions who confined the stakeholder list and limited the questions addressed to them. ${ }^{57}$ Other commissions were more interested in broader questions presenting papers in open academic conferences prior to the reports being published so as to engage with stakeholders, and commissioning private empirical studies prior to writing the reports.

However, this article is examining the extent of interdisciplinarity and the use of non-doctrinal methodologies by lawyers to reform the law. The question, therefore, must be whether the evidence, gathered from the consultations and submissions sent to the law commissions in their enquiries, is being infused into the recommen-

50. R. Macdonald, 'Recommissioning Law Reform', 35 Alberta Law Review 831, at 870 (1996-1997).

51. Ibid., at 875 .

52. W.H. Hurlburt, 'The Origins and Nature of Law Reform Commissions in the Canadian Provinces: A Reply to "Recommissioning Law Reform" by Professor R.A. Macdonald', 35 Alberta Law Review 880 (1996-1997).

53. Arthurs, above n. 5, at 70 .

54. R. Greycar and J. Morgan, 'Law Reform: What's in It for Women?', 23 Windsor Yearbook on Access to Justice 393 (2005).

55. Ibid

56. A. Melville, 'Conducting Law Reform Research: A Comparative Perspective', 28(2) Zeitschrift für Rechtssoziologie 153 (2007), at 153.

57. Ibid., at 158,159 dations? Are the commissions using the submissions in drafting their recommendations? Kieran Tranter's study into the citation practices within the ALRC final reports from 1992 to 2012 found that 'submissions were the most frequently cited source' $(46 \%)$, supporting an argument that 'the best way to influence the executive is to locate recommendations within what can loosely be called the 'community'. ${ }^{58}$ Community participation not only provides 'responses and feedback', it also promotes 'a sense of public 'ownership' over the process of law reform' ${ }^{59}$ However, whether there is a statistical correlation between the number of those respondents supporting a course of action and the final recommendation is more difficult to determine. The submissions are often divided as to their arguments and proposals for the most advantageous way forward. Not all responses are helpful in terms of the information or views they proffer, but the ability to refer back to those providing submissions can assist deliberations. The likelihood is that the recommendations are being based primarily on case law and the arguments provided by the judges and the weight of commission opinion favouring a particular line of action, rather than emanating from the views of those providing submissions. This issue requires further research.

To what extent do the law reform commissions have recourse to academic material on the issues they are studying? Many of the recommendations extend more broadly than simply reforming the legislation - but this very much depends on the scope of the terms of reference handed to the agency. While the reports are referencing legal reforms implemented (and sometimes evaluated favourably) in other jurisdictions, recent examination of the reports produced by the commission has demonstrated a paucity of reference to published academic commentary on the issues they are examining, and also little empirical data to back up the recommendations. ${ }^{60}$ So in Tranter's study, 'citations to secondary academic material in the form of books, journal articles and conference papers were quite low at only $6 \%$ of the total citations'. ${ }^{61}$

There may be clear explanations for this. The reports have narrow terms of reference, and it may be the case that only a very few academic articles are ever directly on point. In addition, the articles and texts referenced in the final reports are in no way fully indicative of the background literature reviews, extensive annotated bibliographies, and working papers produced by the Commissions, and which are never made public; all that is published is the final reports. In the past, publishing costs may have limited the materials that could be released. However, this is certainly not the case at present when electronic files can be easily uploaded onto the websites. It could well be argued that when extensive background research has been undertaken at the public

58. Tranter, above n. 1.

59. R. Atkinson, 'Law Reform and Community Participation', in B. Opeskin and D. Weisbrot (eds.), The Promise of Law Reform (2005), at 160.

60. Tranter, above n. 1, at 349.

61. Ibid. 
expense, then these preliminary working papers should be made available. Until this occurs, it should be queried whether the low level of citation of secondary material truly reflects the background research undertaken for the reports.

A more worrying aspect of the research is the apparent lack of reference in the reports to empirical studies. The literature reviews cover secondary legal literature. There is no evidence of the law reform commissions undertaking literature reviews of the wider social science and scientific evidence base on the issues being covered apart from clarification and definition of existing processes when required. The emphasis always lies on the primary materials - the legislation and case law. The secondary literature is only used to assist in interpreting the law. There is little or no attempt to deal with the wider context apart from what is provided by the submissions and consultations. As Barnett has commented, there is a real need in law reform to 'uncover the facts upon which law reform proposals are based', so that 'they need to see the entire picture and identify the real problem(s) before launching into a search for policy solutions' ${ }^{62}$ So reference is being made to the community stakeholders, and their views on the issues. The law is being considered closely. But very rarely is new data compiled from within the commissions. There are reasons for this. The use of additional interdisciplinary methods is dependent on government budgets. Even attempting to educate the public about an issue can be an expensive process. The commissions focus on the role of clarifying the law for other lawyers and the general public. As detailed previously, the law reform commissions have always performed this role well.

Further research is necessary to determine if there are regularly gaps between existing empirical data, the consultation responses, and the recommendations. However, the recommendations in a law reform report are not the final word. Any major recommendations for legislative change must be presented to cabinet and then parliament for debate. If there are gaps in the arguments presented, then those aspects should be addressed at that point.

\section{Conclusion}

It is clear from this discussion that academic lawyers are using non-doctrinal methods, but they are often infusing these methods within their doctrinal research framework. Definite inroads have been made in relation to the use of comparative approaches. Arguably comparative law, extending far beyond a simple backward glance to the genesis of a legal proposition, is now an intrinsic part of legal scholarship. Published government statistics and the published results of social science research are also being included in doctrinal academic writing to provide contextual framing or to highlight the disparity between the law, social policy, and the existing social evidence base. There are some examples of joint authorship and lawyers working in tandem with those from other disciplines to investigate all sides of the contextual prism in an effort to best achieve enlightened critique. Theoretical and philosophical discussions invariably include footnotes to the doctrinal stasis to provide factual legitimacy. Theory is also increasingly used as a vehicle for critiquing and analysing the basis of the 'black letter' law. Theory is part of the contextual framing. Researchers query - 'What was the pre-eminent theory at the point in history when this law commenced? Are those theories and those economic and political views infused in the law still relevant and valid today?' The doctrinal method remains true to its core, but it is certainly less constrained than in the past.

This article has used examples of existing studies on PhD students' theses, a snapshot of recent articles written by lawyers for Australian law journals and the outputs of the Australian Law Reform Commission to provide some basic assessments of trends in the use of interdisciplinary and doctrinal methods especially focusing on reform agendas. These are Australian examples. Is there any great disparity between Australian legal scholarship and that being undertaken elsewhere? Further empirical study is required on this issue. More research needs to be carried out to determine at what point in the legal analysis the non-doctrinal data is being infused into the discussion and how exactly doctrinal lawyers are infusing this evidence in coming to a conclusion or making recommendations for reform. The discussion has by no means finished. There is evidence of a broadening of the method overall, but we need a more sophisticated study of larger amounts of data to verify the trends observed so far. 